\title{
Behaviour of People Living with HIV Aids in Northeastern Nigeria
}

\author{
Mohammed Tahiru Bolori ${ }^{*}$, Mary Olubisi Amodu1, Isah Muhammad Ahmad², Haruna Yusuph ${ }^{3}$, \\ Jalal-Eddeen Abubakar Saleh ${ }^{4}$
}

${ }^{1}$ Department of Community Medicine, University of Maiduguri, Maiduguri, Nigeria

${ }^{2}$ Department of Biochemistry, Kano University of Science and Technology, Kano, Nigeria

${ }^{3}$ Department of Medicine, University of Maiduguri, Maiduguri, Nigeria

${ }^{4}$ Malaria, Communicable Diseases Cluster, World Health Organization Field Office, Kano, Nigeria

Email: *mtbolori@gmail.com

How to cite this paper: Bolori, M.T., Amodu, M.O., Ahmad, I.M., Yusuph, H. and Saleh, J.-E.A. (2017) Behaviour of People Living with HIV Aids in Northeastern Nigeria. Open Access Library Journal, 4: e3944.

https://doi.org/10.4236/oalib.1103944

Received: September 17, 2017

Accepted: October 28, 2017

Published: October 31, 2017

Copyright $\odot 2017$ by authors and Open Access Library Inc.

This work is licensed under the Creative Commons Attribution International License (CC BY 4.0).

http://creativecommons.org/licenses/by/4.0/

\begin{abstract}
Introduction: Human Behavior is important as one of the determinants of transmission of Human Immunodeficiency Virus (HIV) infection. The risk of getting infected with HIV as well as subsequent developments and reactions after the infection has a direct bearing on human behavior. Positive behavior change of HIV infection prevention is less than the level of awareness and knowledge pertaining the disease among PLWHA. Method: A cross-sectional descriptive study was carried out on PLWHA attending clinic at the University of Maiduguri Teaching Hospital. A structured interviewer administered questionnaire was used to collect data by systematic random sampling technique. The objective of the research was to understand more about the behaviour of PLWHA and make recommendations on how to improve the behavioral change communications among PLWHA to curb the menace of HIV infection. Results: The people living with HIV/AIDs may be knowledgeable and having high awareness on HIV/AIDS but may not necessarily reflect into good behaviors concerning, taking the right steps to prevent menaces of HIV infection. The behavior of PLWHA was found to have gaps that portend danger in regard to making life more miserable to victims and portend more risk of getting others infected. The gaps are mainly related to psychological issues (e.g., lack of enjoyment or with condom use), beliefs, stigma and financial issues. Conclusion: Counselling should be used to inculcate technic, good morals, attitude and practices among PLWHA to prevent them from deliberate or spontaneous attempts to infect others with the virus. Safer and satisfying sex can be promoted through expanding knowledge and awareness about HIV/AIDS and removing stigma among the general populace through community health education as well as through schools' curricula. Empowerment of the youths in public and private settings discourages exchanging sexual in-
\end{abstract}


tercourse for financial gains.

\section{Subject Areas}

Public Health

\section{Keywords}

Behavior, HIV/AIDS, Northeastern Nigeria

\section{Introduction}

Human Behavior is important as one of the determinants of transmission of $\mathrm{Hu}-$ man Immunodeficiency Virus (HIV) infection [1] [2] [3] [4]. The risk of getting infected with HIV as well as subsequent developments and reactions after the infection has a direct bearing on human behavior. One may expect that knowledge of risk factors associated with HIV infection could translate into use of the knowledge by PLWHA to adopt behaviors that help mitigate HIV transmission rate. However, that is not exactly the case currently observed according to Bandawe who asserted that there was so little behavior change amidst so much awareness among the PLWHA [5]. In order to make behavioral changes to curb the menace of HIV infection, there is need to understand more on the pattern of behavior of the PLWHA. Some powerful and insidious determinants of behavior must be identified and addressed to curtail the ravages of HIV transmission [5].

Risky sexual behaviors such as sharing of needles, non-use, inconsistent or incorrect use of condoms during sex are important determinants of HIV infection. People living with HIV/AIDS, PLWHA, infection have significant potential to infect others [4]. Study conducted in Vietnam showed 82 percent of the PLWHA remains sexually active out of which only 30 percent consistently uses the condom during sex [4]. In Malawi, being sexually active is the norm for the youths [4]. Twenty percent of them had been sexually promiscuous with multiple partners. This figure is higher than what was reported in a study conducted on healthy students of University in the northwest region of Nigeria which showed 24.9 percent were sexually active and 8 percent had sex with multiple partners [6]. Fifty percent were injectable drug users a month prior to the study, and 33 percent of them had shared needles [4]. Unsafe sexual behaviors especially inconsistent condom use are practiced by the PLWHA as a significant proportion of this group remains sexually active [7] [8] [9]. The rate of HIV transmission per sexual act was found to be significantly higher among Men Having Sex with Men, MSM, than the heterosexual population [10]. The prevalence rate of HIV infection ranges from 3 percent in the Middle East and North Africa to about 25 percent in the Caribbean. However, HIV prevalence rate stands within the range of 14 to 18 percent among North, South, and Central America, south and southeast Asia, and sub-Saharan Africa [6]. Nigeria has HIV 
infection prevalence rate of 3.4 percent at the national level according to the $\mathrm{Na}$ tional Agency for the Control of Aids, NACA [11]. Borno HIV infection prevalence rate for Borno stood at 2.4 percent [11]. However, NACA holds that states with the highest and lowest prevalence rates recorded were Rivers and Ekiti states respectively. Non-disclosure of HIV sero-status to partner which may be as a result of guilt or other reasons will lead to increased sexual guilt and discomfort that will necessitate intervention to alleviate in order to improve sexual health [11]. Generally, the vulnerable age group of people infected with HIV fall within the age bracket of 15 to 35 years contributing to about 50 percent [7]. However, in Togo, the average age of the respondents stood at $37(\mathrm{SD} \pm 9)$ [8]. Majority of PLWHA in a study conducted in northeastern Nigeria were females and Muslims in terms of gender and religious affiliations contributing to 39.1 percent and 58 percent respectively. As per the marital status, the PLWHA were single, separated, divorced, married and widow(er) contributing to $21,8,12,41$ and 18 percent respectively [7]. Occupation wise of the study by Ajayi et al. revealed that the respondents were mainly civil servants, trading/business, farmers, housewives, students, job seekers contributing to 30, 26, 5, 5, 16 and 17 percent respectively. Societal behaviors continue to play role in shaping behavior of PLWHA in many ways from freedom of expression of their HIV status to their partners, confidants and other relations makes it difficult for them to openly and freely seek for care [12]. Male dominance and stigmatization against PLWHA has made some men to delay disclosing their status to their spouses leading to females seeking for care usually much late [12] [13].

The behavior of persons has been found to intricately influence incidence and prevalence of sexually transmitted and other forms of diseases among humans [1]. Health seeking behaviors, adherent to treatment and sexual behaviors after being infected, continue to be important determinants of HIV transmission after infection [6]. However, the major route of HIV transmission in Nigeria has been found to be through heterosexual sex [7]. It's difficult for MSM to disclose their identity even to the caregivers or close relations because of fear of rejection from most settings [7]. Therefore, it is difficult to elicit an affirmative response to questions dealing with such sensitive issues especially when a gay or homosexual person is the respondent.

Very important behaviors expected to significantly reduce HIV transmission are as published by The AIDS Institute as stated below [14]. Anyone including pregnant women with HIV infection gets care, treatment, and all the other necessary supportive services to help maintain good health and minimize HIV transmission to others. Behaviors that are helpful include abstention from sex, maintain a single or minimal number of sex partner(s) without concealing HIV Sero-status of one another. Maintaining correct and consistent latex condom use, screen and get treatment for other sexually transmitted diseases by all the partners. Adoption of all other behaviors aimed at stopping HIV transmission including drug abuse, hypodermic syringe sharing [14]. Importance of being successfully adherent to drugs was found to be very important in limiting the 
spread of HIV infection among PLWHA [15]. Successful adherences to antiretroviral therapy leads to a good clinical outcome, sustained suppression of viraemia, improved quality of life and overall health of PLWHA. Furthermore, adherence to anti-HIV drug regimen limits the spread of the virus by PLWHA. Being young negatively affects successful adherence anti-HIV drug regimen [15].

\section{Methods}

The study was a cross sectional descriptive study. Data was collected within two weeks, from $25^{\text {th }}$ March to $5^{\text {th }}$ April, 2014. The study population was the patients and clients that registered for care in the Presidential Emergency Program for Aids Relief, (PEPFAR) clinic within the University of Maiduguri Teaching Hospital, Maiduguri of Borno state in northeastern part of Nigeria. Quantitative data were collected using structured interviewer administered questionnaire with closed and open ended questions. The questionnaire was administered by the trained assistants working in the clinic. Systematic random sampling was used to determine respondent by picking on every $5^{\text {th }}$ clinic attendee at the registration for the days' clinics.

Sample size was calculated using the simple formula below as given by Daniel using $95 \%$ confidence interval [16].

$$
n=Z \times Z \times P \times \frac{1-P}{d \times d}
$$

where

$$
\begin{aligned}
& n=\text { sample size; } \\
& Z=Z \text { statistic for a level of confidence; } \\
& P=\text { expected prevalence or proportion (in proportion of one; } 50 \% \text {, was used }
\end{aligned}
$$
for the study. Therefore, value of $P=0.5$ );

$d=$ precision (in proportion of one; if $5 \%, d=0.05$ );

$Z$ statistic ( $Z$ ): For the level of confidence of $95 \%$, which is conventional;

$Z$ value $=1.96$. In these studies, investigators present their results with $95 \%$ confidence intervals (CI).

$$
N=1.96 \times 1.96 \times 0.5 \times(1-0.5) /(0.05 \times 0.05)=384
$$

Attrition rate was arbitrarily estimated as $3 \%\left(384^{\star} 3 / 100=12\right)$

$$
384+12=396
$$

\section{Ethical considerations}

Ethical procedures were adhered, consent of respondents sought and confidentiality maintained. The questionnaires seek to document information on demography, behavior and advice PLWHA had to give. Frequency tables were used to present data collected.

Data analyzed by use of Statistical Software for Social Sciences (SPSS) version 21.

\section{Limitations}

Respondents feel restricted in revealing their true status with regards to sex- 
uality issues such as promiscuity and sexual orientation especially among those that are married. As such the gains in research may not be strictly representative of the rest of the population.

\section{Results}

All the 396 questionnaires served to respondents attracted various responses to the questions, and all were found worthy of being included in the analysis for the study.

All the findings were captured in Table 1 (demographic variables), Table 2 (behaviors of PLWHA) and Figure 1 (advice from PLWHA) as below. The table shows more than 50 percent of the respondents were young people within the age brackets $15-24$ years ( 34.0 percent) and $25-34$ years (19.0 percent). The average age of the interviewees was 26 years ( $\mathrm{SD} \pm 5.4)$. The respondents were married (45.0 percent), civil servants (33.0 percent) in terms of their marital status and occupation.

About 17.0 percent of the respondents belong to pediatric age group, less than 15 years. Educational levels of the majority of the respondents were diploma (21.0 percent), first degree (17.0 percent) or equivalents. About 41.0 percent of the respondents were found to be without any form of education not even qur'anic or religious teachings.

Table 2 shows about 43.9 percent of the respondents were diagnosed positive for HIV testing in the preceding 1 to 5 years. Others were diagnosed positive less than a year before the study or have been confirmed positive 6 to 10 years before the studies. Very few of them were confirmed positive for at least 10 years prior to the study. About 82.0 percent of the respondents remain sexually active for at least 6 months before the study was conducted. However, only 10.0 percent of the respondents consistently used the condom. There were those that never used the condom (4.0 percent) and others who used it sometimes (74.0 percent). It could be seen that 84.0 percent of all the respondents use condom. However,

\section{Percent of main advice by each respondents}

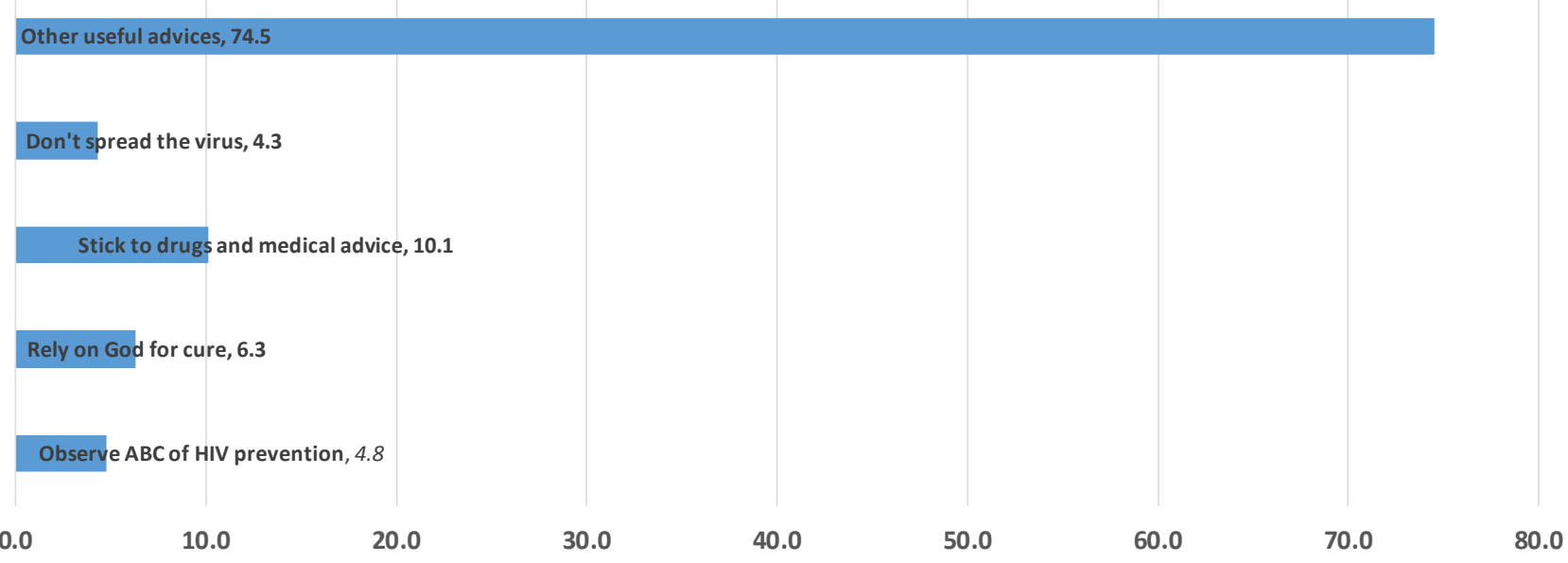

Figure 1. Advice from PLWHA. 
Table 1. Demographic variables.

\begin{tabular}{|c|c|c|}
\hline \multicolumn{3}{|c|}{ Demographic variables $(n=394)$} \\
\hline \multicolumn{3}{|c|}{ Age: Average $=26$ years $(S D \pm 5.4)$} \\
\hline & Frequency & Percent (\%) \\
\hline$\leq 14$ & 67 & 17.0 \\
\hline $15-24$ & 132 & 34.0 \\
\hline $25-34$ & 99 & 25.0 \\
\hline $35-44$ & 60 & 15.0 \\
\hline $45-54$ & 36 & 9.0 \\
\hline \multicolumn{3}{|c|}{ Gender $(n=394)$} \\
\hline Male & 143 & 36.0 \\
\hline Female & 250 & 64.0 \\
\hline \multicolumn{3}{|c|}{ Marital status $(\mathrm{N}=390)$} \\
\hline Single & 116 & 30.0 \\
\hline Married & 177 & 45.0 \\
\hline Divorced & 36 & 9.0 \\
\hline widow(er) & 61 & 16.0 \\
\hline \multicolumn{3}{|c|}{ Religion $(\mathrm{N}=386)$} \\
\hline Islam & 207 & 54.0 \\
\hline Christianity & 179 & 46.0 \\
\hline \multicolumn{3}{|c|}{ Occupation $(\mathrm{N}=395)$} \\
\hline Civil Servant & 132 & 33.0 \\
\hline Trading & 82 & 21.0 \\
\hline Farming & 34 & 9.0 \\
\hline House Wife & 66 & 17.0 \\
\hline Others & 6 & 2.0 \\
\hline 6 & 75 & 19.0 \\
\hline \multicolumn{3}{|c|}{ Educational level $(\mathrm{N}=371)$} \\
\hline None & 152 & 41.0 \\
\hline Qur'anic & 4 & 1.0 \\
\hline Primary & 20 & 5.0 \\
\hline Secondary & 28 & 8.0 \\
\hline Diploma/NCE & 76 & 21.0 \\
\hline First Degree/HND & 63 & 17.0 \\
\hline Advance Level & 1 & 0.3 \\
\hline 0thers & 27 & 7 \\
\hline
\end{tabular}


Table 2. Behavior and other attributes of PLWHA.

\begin{tabular}{|c|c|c|}
\hline & Frequency & Percent (\%) \\
\hline \multicolumn{3}{|c|}{ Number of years since diagnosed as infected with HIV $(\mathrm{N}=396)$} \\
\hline Less than 1 year & 120 & 30.3 \\
\hline 1 - 5 Years & 174 & 43.9 \\
\hline $6-10$ Years & 79 & 19.9 \\
\hline More than 10 years & 22 & 5.6 \\
\hline \multicolumn{3}{|c|}{ Number of sexual partners of respondents in the preceding 6 months $(\mathrm{N}=395)$} \\
\hline none & 56 & 14.0 \\
\hline one & 206 & 53.0 \\
\hline $2-4$ & 107 & 27.0 \\
\hline$\geq 5$ & 9 & 2.0 \\
\hline \multicolumn{3}{|c|}{ Use of condom by respondent during sex $(\mathrm{N}=381)$} \\
\hline never & 15 & 4.0 \\
\hline Sometimes & 282 & 74.0 \\
\hline Always & 38 & 10.0 \\
\hline Not Applicable & 46 & 12.0 \\
\hline \multicolumn{3}{|c|}{ Reasons for condom use by respondent $(\mathrm{N}=325)$} \\
\hline Prevent spread to others & 19 & 5.8 \\
\hline Prevent getting more viruses from others & 111 & 34.2 \\
\hline Prevent pregnancy & 195 & 60 \\
\hline \multicolumn{3}{|c|}{ Does respondent know HIV sero-status of partner $(\mathrm{N}=390)$} \\
\hline Negative & 31 & 7.9 \\
\hline Positive & 211 & 54.1 \\
\hline Don't Know & 82 & 21.0 \\
\hline Not Applicable & 32 & 8.2 \\
\hline Some positive and some Negative & 34 & 8.7 \\
\hline \multicolumn{3}{|c|}{ Change in attitude after infection with HIV $(\mathrm{N}=329)$} \\
\hline Become more serious about STIs preventive measures & 67 & 20.4 \\
\hline It does not matter being careful or not & 20 & 6.1 \\
\hline Careful not to spread the disease & 135 & 41.0 \\
\hline Regularly comply with medical advice & 107 & 32.5 \\
\hline \multicolumn{3}{|c|}{ Sexual orientation of respondents $(\mathrm{N}=387)$} \\
\hline Heterosexual & 381 & 98.4 \\
\hline Homosexual & 5 & 1.3 \\
\hline Bisexual & 1 & 0.3 \\
\hline
\end{tabular}


60.0 percent of all the respondents use condom for prevention of pregnancy living only 24.0 percent that uses condom solely for prevention of sexually transmitted infections, STIs. Up to 62.0 percent of PLWHA in the study sample know their partners' HIV status (54.1 percent were positive and 7.9 percent negative). About 21.0 percent of the people interviewed didn't know their partners' HIV status. Some 8.2 percent of the respondents deal with a combination of both HIV positive and HIV negative partners. It was deduced from Table 2 that 83.3 percent of all respondents had attitudinal change due to their HIV positive status in different ways such as being more serious about preventive measures of STIs (20.4 percent), more serious not to spread the disease (41.0 percent), heedless of being careful against HIV (6.1 percent) regularly comply with medical advice (32.5 percent). Almost all the respondents claimed to be heterosexuals (98.4 percent). However, five respondents ( 1.3 percent) and one other ( 0.3 percent) admitted being gay or lesbian and bisexual respectively.

\section{Discussion}

The valuable advice for the PLWHA found in the study include; not to spread the virus (4.3 percent), stick to drugs and medical advice (10.1 percent), rely on God for cure (6.3 percent), observe ABC of HIV prevention (4.8 percent) and other pieces of advice ( 74.5 percent). The average age of the respondents was 26 $(\mathrm{SD}=5.4)$ which means the majority of the PLWHA are young as found in other studies [7] [8]. That was not surprising as the young were known to be sexually more active and more vulnerable to HIV infection. Also, it is very challenging for young people to adhere strictly to anti-retroviral treatment [15]. It is not surprising that 41 percent of the PLWHA interviewed did not have any form of education. About 38 percent were at least diploma certificate holders as literacy level in the northeast was known to be the lowest in the country. Majority of respondents being females was consistent with the findings of Ajayi et al. within the same geographic area most probably because females are known to be better in health seeking behavior than males [7]. Besides, the proportion of women with HIV infection (60.0 percent) was found to be higher than in men [7]. The proportion of the Christian respondents was lower because Islam is the dominant religion in the northeast of Nigeria. Majority of the participants in the study were single as only 41.0 percent were married. The remaining except for the pediatric age group (17.0 percent) were single. Being a sexually matured young person and single portrays more vulnerability towards HIV infection through sex to or from the person concerned. About 70.0 percent of the respondents knew their HIV Sero-status as positive for at least a year before the study. Little above 5.6 percent had harbored the virus for at least 6 years. The majority (80.0 percent) of the respondents were sexually active as obtains in the study conducted in Vietnam (82.0 percent). [4] Up to 74.0 percent of that proportion was not consistent and correct users of the condom. Only 10.0 percent out of the sexually active respondents use condom always during sex. That was far less 
than in the Vietnam study where about 30 percent correctly and consistently use the condom [4]. Behavioural factors that affect the consistent and correct use of a condom include issues of intimacy and trust in partner, less enjoyment with use of a condom during sex, agreement on prize to have sex without a condom [6]. The PLWHA use condoms for different reasons. Only about 5.8 percent of the respondents use the condom to protect others or their partners from getting infected with the disease. Up to 34.2 percent use condoms to protect themselves from getting the virus from others. However, the larger proportion of the respondents actually uses the condom to prevent unwanted pregnancies. The finding that higher proportion of PLWHA uses condoms to avoid unwanted pregnancies is similar to what is found in a study among the general population of students in the northwestern University in Nigeria [6]. Unwanted pregnancies are due to many reasons such as economic reasons, beliefs, stigma and other personal reasons. However, what is common to both pregnancies outside of marriage and HIV/AIDS is the stigmatization [6] [12]. Higgins et al. documented a study that showed the association between condom use and greater sexual satisfaction [12]. This fact needs to be explored more because it could be convincingly used as a selling point as it could be included in social marketing message to boost condom use [12]. There are occurrences of anecdotal speeches revealing that use of condom prolongs male orgasm thereby increasing sexual satisfaction among females. Significant attitudinal changes among the respondents were getting more serious about sexually transmitted infections, STIs, (20.4 percent), being careful not to spread the disease (41.0 percent) and regularly comply with medical advice (32.5 percent). Those whose attitudinal change was to comply with medical advice proves that they had not been adherent to medical advice and most their prescriptions too. However, some of the respondents felt it does not matter whether or not being careful (6.1 percent). The pieces of advice given by the PLWHA most probably reflect shortcomings from which they might have changed for the better. Majority as disclosed their sexual orientation as heterosexual (98.4 percent), gay or lesbians (1.3 percent) and only 1 person ( 0.3 percent) revealed being bisexual. This part is sensitive and as such the respondents may not be revealing the truth about their sexual orientations for fear of being stigmatized at [12].

\section{Recommendations}

There is the popular slogan that the ABC of HIV prevention can be promoted into being practiced by a greater number of people if counselling is done very well for all PLWHA in pre- and post-voluntary counselling and trial, VCT. Proper counselling may promote beneficial behavioral changes.

Counselling should be used to inculcate good morals, attitude, and practices among PLWHA to prevent them from deliberate or spontaneous attempts to infect others with the virus.

Knowledge and awareness about HIV/AIDS infection prevention need to be 
expanded among PLWHA and the general population to prepare them for more satisfying and safer sexual relationships. This can be done through community health education as well as through schools' curricula.

Empowerment of the youths in public and private settings to discourage exchanging sexual intercourse for financial gains will go a long way in prevention of HIV infection.

Communities should be enlightened through various media to debunk issues linked to stigmatization which makes it difficult for some PLWHA to confide their HIV Sero-positive status in their partners and close relations.

\section{References}

[1] Funk, S., Salathe, M. and Jansen, V.A.A. (2010) Modelling the Influence of Human Behavior on the Spread of Infectious Diseases: A Review. Journal of the Royal Society Interface, 7, 1247-1256. https://doi.org/10.1098/rsif.2010.0142

[2] Centers for Diseases Control. (2015) HIV Risk Behaviors. https://www.cdc.gov/hiv/risk/estimates/riskbehaviors.html

[3] Rosen, D.L., Schoenbach, V.J., Wohl, A.D., White, B.L., Stewart, P.W. and Golin, C.E. (2009) Characteristics and Behaviors Associated with HIV Infection among Inmates in the North Carolina Prison System. American Journal of Public Health, 99, 1123-1130. https://doi.org/10.2105/AJPH.2007.133389

[4] Thanh, D.C., Hien, N.T., Tuan, N.A., et al. (2009) HIV Risk Behaviours and Determinants among People Living with HIV/AIDS in Vietnam. AIDS and Behavior, 13, 1151. https://doi.org/10.1007/s10461-008-9451-8

[5] Bandawe, C.R. (2002) Revisiting Human Behaviour in Relation to HIV/AIDS. Malawi Medical Journal: The Journal of Medical Association of Malawi, 14, 27-28.

[6] Bolori, M.T., Aliyu, A.A. and Lawan, U.M. (2014) Perceptions of Sexual Behavior and Knowledge on Sexually Transmitted Infections among Undergraduate Students of University in North Western Nigeria. Kanem Journal of Medical Sciences, 4, 32-37. http://kjmsmedicaljournal.com/publications/kjms_4_2_Bolori_MT.pdf

[7] Beyrer, C., Baral, S.D., Griensven, F., Goodreau, S.M., Chariyalertsak, S., Wirtz, A.L. and Brookmeyer, R. (2012) Global Epidemiology of HIV Infection in Men Who Have Sex with Men. The Lancet, 380, 367-377. https://doi.org/10.1016/S0140-6736(12)60821-6

[8] Ajayi, B., Moses, A., Gashau, W. and Omotara, B. (2013) Assessment of Knowledge, Perception and Attitude of People Living with HIV/AIDS towards HIV/AIDS in Maiduguri, Northeast of Nigeria. Internet Journal of Infectious Diseases, 12, 1. https://print.ispub.com/api/0/ispub-article/1382

[9] Yaya, I., Saka, B., Essoya, L., Patchali, P.M., Makawa, M., Senanou, S., et al. (2014) Sexual Risk Behavior among People Living with HIV and AIDS on Antiretroviral Therapy at the Regional Hospital of Sokodé, Togo. BMC Public Health, 14, 636. https://bmcpublichealth.biomedcentral.com/articles/10.1186/1471-2458-14-636

[10] Du, P., Crook, T., Whitener, C., Albright, P., Greenawalt, D. and Zurion, J. (2015) HIV Transmission Risk Behaviors among People Living with HIV/AIDS: The Need to Integrate HIV Prevention Interventions and Public Health Strategies into HIV Care. Journal of Public Health Management \& Practice, 21, E1-E10. http://www.ncbi.nlm.nih.gov/pubmed/24335609

[11] National Agency for the Control AIDS (2014) Nigeria Prevalence Rate. 
http://naca.gov.ng/

[12] Higgins, J.A., Mullinax, M., Trussell, J., Davidson, K. and Moore, N.B. (2011) Sexual Satisfaction and Sexual Health among University Students in the United States. American Journal of Public Health, 101, 1643-1643.

https://doi.org/10.2105/AJPH.2011.300154

[13] Mbonu, N.C., Borne, B.V.D. and Devries, N.K. (2011) The Experiences and Complexities of Care-Seeking Behavior of People Living with HIV AIDS: A Quantitative Study in Nigeria. http://www.intechopen.com

[14] The AIDS Institute (2011) How Can HIV Be Prevented? http://www.theaidsinstitute.org/print/263

[15] AIDS info (2014) Guidelines for the Use of Antiretroviral Agents in HIV-1-Infected Adults and Adolescents.

https://aidsinfo.nih.gov/guidelines/html/1/adult-and-adolescent-arv-guidelines/30/a dherence-to-art

[16] Naing, L., Winn, T. and Rusli, B.N. (2006) Practical Issues in Calculating the Sample Size for Prevalence Studies. Medical Statistics. Archives of Orofacial Sciences, 1, 9-14. https://www.scribd.com/doc/63105077/How-to-Calculate-Sample-Size

Submit or recommend next manuscript to OALib Journal and we will provide best service for you:

- Publication frequency: Monthly

- 9 subject areas of science, technology and medicine

- Fair and rigorous peer-review system

- Fast publication process

- Article promotion in various social networking sites (LinkedIn, Facebook, Twitter, etc.)

- Maximum dissemination of your research work

Submit Your Paper Online: Click Here to Submit

Or Contact service@oalib.com 